\title{
Preparing Business Education Teachers for Effective Implementation of Student-Centred Learning Strategies in the E- World
}

\author{
Timothy Olusegun EEBO, PhD $^{1}$, L.F. ADEMILUYI, PhD ${ }^{2}$ \\ ${ }^{1,2}$ Department of Business and Entrepreneurship Edu Kwara State University, Malete. Nigeria
}

\begin{tabular}{|c|c|}
\hline ARTICLE INFO & ABSTRACT \\
\hline $\begin{array}{l}\text { Publication Online: } \\
\text { 07 January } 2022\end{array}$ & $\begin{array}{l}\text { This paper highlights preparing business education teachers for effective implementation of student- } \\
\text { centred learning strategies in the e- world. The paper defines terminologies such as Student-centred } \\
\text { learning, e-learning and the need for linking ICT to education policies. It examines the world links } \\
\text { program with student-centered teaching and learning web sites as well as discusses main } \\
\text { characteristics of student-centered strategies and its popular types. It further discusses learning } \\
\text { situations in the field of business education, teacher's role in student-centred strategies with } \\
\text { implication of using student-centred strategies in Nigeria business education programme and analysis } \\
\text { of threats to student-centred strategies. The paper concludes by making recommendation on the way } \\
\text { forward among which Teacher should encourage student interaction in utilizing e-libraries or e-world }\end{array}$ \\
\hline $\begin{array}{l}\text { Corresponding Author: } \\
\text { Timothy Olusegun } \\
\text { EEBO }\end{array}$ & $\begin{array}{l}\text { at large in class participations. Institutions should encourage teachers in using student-centre } \\
\text { strategies by sending them to seminal, conference/ workshop that base on this purpose. And institution } \\
\text { should make available internet service } 24 / 7 \text { with power supply in the schools and staff quarters. }\end{array}$ \\
\hline
\end{tabular}

\section{INTRODUCTION}

The world is advancing everyday in every facet of life. The need for adequate utilization of the right experiences in the area of teaching and learning especially when the teaching is inductive in nature cannot be overemphasized. Adequate preparation must be made by the teacher before lesson so as to have desire goal realized logically, most especially in student-centred learning. Student-centred learning is a learning that pays close attention to knowledge, skills, attitudes, and beliefs that learners bring into the learning process where its impetus is derived from a paradigm of learning called constructivism. Meanwhile, one of the objectives of business education is the preparation objective recognizes that schools have an obligation to provide background preparation in business as well as to develop skills that provide students with the tools to cope more effectively with college demands (ABEN,2017)

Student-centred learning emphasizes transparent procedures for students to be able to give feedback on the quality of the educational process, students are consulted on curriculum content, on the teaching and evaluation methods used, periodic programme quality reviews, Student also enjoy full and equal membership in committees. It provides procedures for students to appeal decisions regarding their academic attainment or progression. Students are consulted when learning outcomes are designed: student needs and the diversity of the relevant student group are considered when designing learning activities and outcomes, students are informed on the intended learning outcomes before they start a course or programme component. Representatives of teachers and students are involved as full and equal members in the panels undertaking quality assurance reviews, institutional quality assurance reviews while guidelines take into account the overall elements of teaching and learning. Prior learning is recognized by the institution for the purpose of access into educational programmes, the process of recognition is easy, and recognition of prior learning can be done without significant costs or bureaucracy. There are special support measures in place in order to help students from disadvantaged backgrounds; learning paths are flexible enough so as to permit combining work/family life and studies, group-work is used in the learning process, the goals of the learning process are agreed upon between teachers and students, peer and self-assessment are used as a method in the student assessment process while projects are used in the assessment of students. Furthermore, simulations of tasks and real life situations are used in the assessment of students, students have access to appropriate research and study facilities, the institution contributes to promoting a national culture of student-centred learning, the programme uses a 
student-centred learning approach in providing training on the use of innovative teaching methods and student-centred curriculum development. Additionally, in the classroom, there is practical implementation of student-centred learning approach that includes a number of following components: problem-based learning, group project work, student-centred active learning, resource-based learning, use of the case method, role plays, classroom workshops, group presentations, use of a web-conferencing environment, particularly in distance education, small group work that enables students to learn how to work in a team, in the process of which they identify and fill the gaps in their knowledge. These also stress the importance of involving students after the task is completed, making self assessment comments, making peer-assessment feedback comments, suggesting self assessment grades and negotiating self-assessment grades (Student-Centred Learning. 2014).

The learning process can be enriched in many subjects because of the scale and range of information provided by computer data bank. E-learning is a learning program that makes use of information network- such as the internet, an intranet (Local Area Network), (Metropolitan Area Network). extranet (Wide Area Network) or (World Wide Web) whether wholly or in part, for course delivery, interaction and/or facilitation. Web-based learning is a subset of e learning and refers to learning using an internet browser such as the Modular Object-Oriented Dynamic Learning Environment, blackboard or internet explorer (Tamelis, 2014).

The need for linking ICT according to Hoidn (2016) education policies requires recognition. In reflecting the importance of technologies, education policies should focus in the following major points:

(1) Education policies have to reflect alternate and new teaching paradigms that ICT can offer in terms of providing a more effective, relevant, and flexible mode of learning for the underprivileged and the general masses.

(2) Policies must take into account the retraining of teachers incorporating use of ICTs in education. Teachers should skillfully redesign learning environments so that students can transfer their newly gained ICT skills to other applications to use in an ICT rich environment.

(3) Most educational policies reflect the need for ICT infrastructure but they left out the need for local educational content. The development of instructional content-ware remains a neglected area, affecting investments in hardware and resulting in a heavy economic and educational loss.

(4) The focus of developing countries should be on how to use ICTs to compensate for the factors that are lacking in education, namely, well-trained teachers and the resources to pay for expensive equipment. The task is to concentrate on technological alternatives that, at low cost, bring to students the imagination and creativity of a few excellent teachers.

\section{THE WORLD LINKS PROGRAM}

The World Links program is a good initiation in the form of a project, originally managed by the World Bank to place internet-connected computers in secondary schools and train teachers in Africa, Latin America, the Middle East, and South and Southeast Asia. The goal of the program is to improve educational outcomes, economic opportunities, and global understanding for youth using information technology and new approaches to teach (The World Bank Group, 2017). Services provided by the program include:

1 Feasibility studies and consultation on connectivity solutions and tele-center management.

2 Internet connectivity for secondary schools in developing countries.

3 School-to-school partnerships, as well as regional and global partnerships with public, private and nongovernmental organizations.

4 Teacher professional development on issues of technology in the context of innovative pedagogy.

5 Workshops for policy makers on coordination of policies and implementation strategies.

With the help of the World Links program, many countries are now using ICTs as ways of providing teachers with new skills and introducing innovative pedagogies in the classroom. For example, teachers in Nigeria acquired familiarity with computers for professional (e.g. student marks, parent reports) and outof-classroom tasks (e.g. searching for educational content on the web and lesson-planning activities). The program also provides 200 hours of teacher training that include an introduction to ICT, use of the internet for teaching and learning, use of tele-collaborative learning projects, integration of ICTs into the curriculum and teaching, and innovative pedagogical approaches. Because of this, majority of teachers and school principals report that teachers trained with computer and teaching skills gained positive attitudes about technology and about teaching. Moreover, some Africa countries such as South Africa, Ghana, Kenya, Tunisia and Nigeria realized the importance of ICT integration to their education policies. They are also investing in ICT infrastructure for schools and creating network links of education institutions.

\section{STUDENT-CENTRED TEACHING AND LEARNING WEB SITES}

A number of web-site has developed effective studentcentred platforms which can facilitate and enhance student- 
centred teaching and learning among which include the following as identified by Felder (2018);

1. Ted Panitz's home page. A vast collection of resources on cooperative and problem-based learning including an e-book, articles, faculty surveys, examples, and links to many other sites, compiled by Ted Panitz of Cape Cod Community College.

2. Active/Cooperative Learning: Best Practices in Business Education. A collection of resources compiled by the Foundation Coalition, including excerpts from videotaped interviews with some of the leading practitioners of cooperative learning in business education on different aspects of planning and implementation.

3. Guide to Active and Cooperative Learning. Handouts, some videos, and links to a number of other sites related to these two instructional strategies. This resource is part of the "Guide to Online Schools" (colleges and universities) web site.

4. National Center for Case Study Teaching in Science. A large collection of resources for case-based instruction housed at the University of Buffalo.

5. Business Case Studies. A collection of case studies in business education archived at the Center for Case Studies in business at Chicago state University.

6. IASCE. The web site of the International Association for the Study of Cooperation in Education. A collection of resources including a newsletter, list of related organizations and links, and a search engine.

7. Deliberations on Problem-Based Learning. Links to sites related to problem-based learning.

8. NISE. The web site of the National Institute for Science Education at the University of Wisconsin. Resources on collaborative learning (including Cooper and Robinson's outstanding annotated bibliography on cooperative learning), learning through technology, and assessment of learning.

9. Just-in-Time Teaching Web site. Techniques and resources for just-in-time teaching.

10. Problem-Based Learning Clearing house. Problems that have been used as the basis of problem-based learning activities in different disciplines and articles about problem-based learning. Resources for inquiry-based learning in accounting can also be found at Business Connections and The Bus Collective.

11. Process-Oriented Guided Inquiry Learning (POGIL). Information about and resources for a team-based approach to inquiry learning that has been applied principally in accounting curricula.

12. STEM Meta-Analysis. A meta-analysis of the effects on group work on student performance and attitudes in science, technology, engineering, and mathematics compiled by Leonard Springer, Mary Elizabeth Stanne, and Samuel Donovan. Some of the most powerful existing evidence of the effectiveness of cooperative learning.

13. The University of Minnesota Cooperative Learning Center. Information and references on different aspects of cooperative learning, including "Cooperative Learning Methods: A Meta-Analysis," which summarizes the results of a large number of cooperative learning research studies. The site is maintained by David and Roger Johnson of the University of Minnesota.

\section{MAIN CHARACTERISTICS OF STUDENT- CENTRED STRATEGIES}

Characteristics that fit for evaluation to know if a methodology is learner-centred:

1. The method should be intrinsic motivation instead of extrinsic motivation focuses on the degree to which an individual's behavior is self-motivated and 'self-determined'. When students are given the opportunity to gauge their learning, learning becomes an incentive (self-determination theory).

2. It must based on the learner's needs and interests, means inverting the traditional teacher-centred understanding of the learning process and putting students at the centre of the learning process.

3. The teacher's goal in the learning process is to guide students into making new interpretations of the learning material, thereby 'experiencing' content, reaffirming Rogers' notion that "significant learning is acquired through doing. Therefore the goals and how to assess them are set not by the teacher alone, but by the learners (together with the teacher in some cases).

4. The learners decide how they want to demonstrate mastery of the skills or competencies.

5. The learners have a role in making decisions about how and when to learn, as well as the pace in which they will learn.

\section{Popular Types of Student-Centred Strategies}

Among the most often mentioned types of studentcentred learning are;

1. Problem-based learning as described by Mamman (2016) as an active earning approach which was first developed in medical education. Before students start learning, they are acquainted with a problem and then have to learn some new knowledge about the topic in order to solve the problem. Students 
receive information about PBL process, rules of working in cooperative groups, the objectives, the requirements roles, and the assessment strategies. The teacher actsas a facilitator who guides students' earning through the learning cycle.

2. Project- based learning is one the most known and used learning strategies, requires that students are actively involved in learning (Eebo and Umoru,2019). Project-based learning involves students in complex projects that require problemsolving, research activities, decision making and realistic products or presentations

3. Learning contracts as a teaching method ensures that students plan their learning experiences together with lecturers. Brecko (2004) asserted that the main advantages of the learning contract are that learning is of interest to the learner, it motivates him, the learner is free to choose the area of learning, learners can learn at their own pace, students are focused upon their learning, the learning contract respects differences in individuals and that it increases confidence and excitement in learning. Frank and Scharf (2013) find that learning contracts give opportunities for self-directed learning that fosters greater accountability, responsibility and commitment. The learning contract has proven to be among the best ways to stimulate active approaches to learning and to acquaint students with the research process because it makes students take an active role in defining and fulfilling their learning.

4. Flexible (cooperative) learning as a method where students may negotiate with their lecturers on matters such as choice of topic areas, use of support materials such as textbook and web resources, timetable and venues for meetings with their instructors and the nature and weighting of individual assessment tasks. Students have some autonomy over how, when, where and what to learn. In this way, flexible learning takes account of the individual needs of students and therefore implies a more 'student-centred' approach to learning

5. Self-directed learning as an essential part of problem-based learning, Self-directed learning should not be considered just as self-study and/or students' own concern. Self-directed learning means that students have to study from the corresponding sources of literature in order to develop information literacy skills/competences. Information literacy is one of the most important factors for the development of problem-based learning. Problembased curricula offer many opportunities to include information literacy as a natural part of the learning process. Silen and Uhlin suggest that it is necessary to give the students the freedom to search and make choices about what to read, but they also need challenges, support and feedback to develop information literacy. In this regard university teachers can get a great help from librarians who are experts on information literacy. They can support the students' views on the information that they need to start thinking about problem-based learning. Librarians are important not just as providers of information literacy but should be included in problem-based learning as people who could help teach students how to become lifelong learners.

6. Inquiry-based learning requires students' active learning by exploring data, scenario in seeking information (Eebo, 2019). Inquiry learning usually starts with questions and not with lectures. Students work in teams and examine data or explore models. Plush mentions a number of researchers who believe that inquiry learning improves problem solving skills, understanding and motivation. There are also some opinions that inquiry learning has negative effects on the content coverage.

7. Just-in-time checking is a type of student-centred learning developed by Novak,Patterson, Gavrin and Christian for undergraduate courses. Which involves the use of online activities in the form of short-answer and multiple-choice questions that students are required to complete just prior to attending a lecture.

8. Personalized learning according to Johnson (2004) was first used by British politicians who stressed that personalized learning means really knowing the strengths and weaknesses of individual students, the necessity of developing the competence and confidence of each learner through teaching and learning that builds on individual needs, that every student should enjoy the study choice, that it requires a new school organization, and that the community should support.

\section{LEARNING SITUATIONS IN THE FIELD OF BUSINESS EDUCATION}

Business education adapts the method form medical students in introducing the student-centred strategies. Milanese, Gordon, and Pellatt (2013) discuss the following learning situations in the field of business education (Accounting, Marketing Research and Typewriting):

The student identifies a topic in the curriculum content and source for materials on the topic with the help of educator facilitates the process. The student will be allow presenting those facts for criticism from other students by which student observes another student during practice while the educator facilitates reflection after a demonstration and request for documentation of all facts in a single note for 
evaluation on the topic treated by students (student-centred activities)

Student can pick themselves one no one for tutorial revolving on course material prepared by the course lecturer; student participates in small group discussion on the topic, tutored by a fellow student and later presents a case study to fellow students and lecturer (discussion) the lecturer gives verbal feedback about solution and gives written feedback about solution on what the student did well, the student's limitations, the student's knowledge, the student's skill, the student's attitude (feedback to the student).

The student assesses him/her self on participatory level, assessed by other students on participatory level, the topic regarding answers to case. The lecturer assesses the student using continuous assessment test situation and at the end of the semester examination (student assessment)

The student can performs role-play activities during micro-teaching, teaching practice and industrial training both the educator and student plan learning activities for teaching practice and industrial training together. This help student draws up a SWOT analysis of his/her learning abilities, performs self reflection tasks on teaching abilities and writes a report on industrial training, the student makes a presentation, evaluates an outcome measure from microteaching and industrial training, writes a report on evidence based skills, competency and attitudinal change that have been developed in process for assessment.

The study found out that the most valuable activities for students were individual student-centred learning activities with adequate discussion and immediate feedback that informed students about their limitations, skills, knowledge and attitude. The worst learning opportunities were those that were not directly participate in the process.

\section{TEACHER'S ROLE IN STUDENT-CENTRED STRATEGIES}

Student-centred strategy is based on the empirically proved hypothesis that students achieve superior academic results and even personal growth in terms of higher self-confidence, openness to experience. if they learn in an atmosphere or climate that can be characterized by three basic attitudinal conditions: realness, acceptance, and empathic understanding. These necessary and sufficient conditions must be held or lived by the instructor, better facilitator, and reciprocally be perceived by the students.

1 Realness, genuineness, or transparency in the facilitator means that he or she must be real in the relationship with student, be the person he/she is and not use any masks or facades in communicating with the students.

2 Acceptance, prizing, or respect towards students implies that the facilitator accepts and respects the whole personality of the student and feels basic trust in his or her constructive tendency, his/her striving for solutions in his/her own way.

3 Deep understanding, often called empathic understanding, means that the facilitator actively listens to the students with the ultimate goal to profoundly understand their questions, motivations, intentions, and the meanings of their communication as well as solutions

Aspy(2015) observes that the key players in creating study quality improvement conditions are teachers. The following requirements for teacher were identified:

1 ability to construct a study process oriented towards development of the students' competences;

2 create conditions for students' personal development;

3 apply appropriate methods for the assessment of the study results (from the students' point of view, formative assessment is very important).

4 pay special attention to the development of the students' creativity.

The key role in assisting students to become self-directed learners lies behind teachers. Gibbon (2015) introduced the idea of a bridge both for students and teachers, a bridge of five stages each involving a new set of tasks, and together providing steps in a gradual transition to self-direction. These five stages are:

1 Incidental self-direction: This involves introducing self-direction in assignments, special projects or brief use of any of the other approaches to selfdirection

2 Independent thinking: teaching students to form their own judgments, ideas and solutions to problems by transforming the curriculum into questions or by using such participatory approaches as case studies, trials, debates and dramatizations

3 Self-managed learning: creating guides that tell students how to achieve course outcomes, then teaching them how to regulate their work on the guides, and providing support systems to assist them;

4 Self-planned learning: teaching students how to design their own plans for achieving course outcomes, negotiating their proposals with them, and coaching them to success;

5 Self-directed learning: teaching students to analyze the situation formulate their own goals, plan how to achieve them, take action, solve problems that arise, and demonstrate their achievement.

\section{USING STUDENT-CENTRED STRATEGIES IN NIGERIA BUSINESS EDUCATION PROGRAMME}

Business Education Programme as a sub-set of vocational education that equips an individual with functional and suitable skills for a meaningful living. The programme 
employed multi-various methods of teaching and learning in imparting knowledge, skills and competency in its offerings. Student-centred methods have repeatedly been shown to be superior to the traditional teacher-centered approach to instruction, a conclusion that applies whether the assessed outcome is short-term mastery, long-term retention, or depth of understanding of course material, acquisition of critical thinking or creative problem-solving skills, formation of positive attitudes toward the subject being taught, or level of self-confidence in knowledge and skills especially in Business Education. The success of this initiative was evaluated by surveying the students. After two years, the mean ratings indicating the students' perception of the quality of the teaching and learning environment at the university all rose significantly. The study is one of many examining the process of implementing student-centered methodology in Business Education Programme in large institutions of higher education in Nigeria.

\section{ANALYSIS OF THREATS TO STUDENT-CENTRED STRATEGIES}

Among the most serious threats of the contemporary studentcentred learning is overload of teachers in the new system. A student-centred learning teacher should know the scientific area, be acquainted with pedagogy and didactics, know how to prepare study materials, make connections with libraries through internet and be an ideal facilitator. Teachers do not receive all this during their studies and it is also difficult for them to acquire this knowledge in the first year of their work with the following environmental threats

Political environment; The inter-variance of government at all levels has greater impact academic stability in the nation though universities' policies are said to be autonomous but in reality they are subject to the ministries of education and to governments. The procedures of changing laws and rules on university education are very long. Therefore no matter effective the method of teaching employed without good political environment the effort is a waste.

Economic environment; Economic environment affects the finances that are used for universities. If the current economic crisis in Nigeria continues, teachers' salaries will remain on the same level. With that the out-put performance of teachers are diminishing each day.

Social-cultural environment; The number of people who believe in student-centred learning is growing. Particularly important is development of better relationships among teachers and students.

Technological environment; Information technology in the modern world enables different ways of teaching and offers new opportunities also for student-centred learning.

\section{CONCLUSION}

The importance of adequate teacher preparation for studentcentred strategies has come to stay in the changing world of work and e-world. There is an urgent need for teacher/ facilitator to permit student interact directly with the content of study to allow proper retention and allow individuality in learning. To present our graduates as international ambassador of our great institutions student-centred learning strategies should reinforce in today e-world.

\section{RECOMMENDATIONS}

To encourage adequate teacher preparation for studentcentred strategies in business education programs the following are recommended:

1 Teacher should prepare adequate leading questions/cases/scenario that can motivate self learning in business education

2 Teacher should encourage student interaction in utilizing e-libraries or e-world at large in class participations

3 Institutions should encourage teachers in using student-centre strategies by sending them to seminal, conference/ workshop that base on this purpose.

4 Institution should make available internet service $24 / 7$ with power supply in the schools and staff quarters

5 Government should formulate and implement policies that will enhance at the same time motivate teachers at all levels utilize studentcentred strategies.

\section{REFERENCES}

1. ABEN (July,2017).Mandate of Business Education in Nigeria. Integrity Publication, Ilorin Kwara State.

2. Aspy, D. N. (2015) Toward a Technology for Humanizing Education, Champaign (IL) Research Press Company.

3. Brecko E.(2010).Facilitating Independence Amongst Chinese International Students Completing a Bachelor of Applied Business Studies Degree", Innovations in Education and Teaching International, 47 (4).

4. Felder R.M. (2011)."Hang in There: Dealing with Student Resistance to Learner-Centered Teaching." Chem. Engr. Education, 45(2), 131-132.

5. Fernandes, S., Mesquita, D., Assunção Flores, M., Lima, R.M. (2014) Engaging students in learning: findings from a study of project-led education, European Journal of Engineering Education, 39 (1), pp. 55-67.

6. Frank, T. (2016) Learning Contracts in Undergraduate Courses: Impacts on Student Behaviors and Academic Performance, Journal of the Scholarship of Teaching and Learning, 13 (4).

7. Gibbons, M. (2015). Pardon Me, Didn't I Just Hear A Paradigm Shift (2004) Available at: 
http://www.Selfdirectedlearning.com/teaching-selfdirected-learningtools/articles/paradigm-shift.html [Accessed 15 January, 2015]

8. Hoidn, Sabine (2016). Student-Centered Learning Environments in Higher Education Classrooms. New York, NY: Palgrave Macmillan

9. Johnson,Eli (2013). The Student Centered Classroom: Vol 1: Social Studies and History. p. 19. ISBN 1317919491.

10. Milanese, S., Gordon, S. Pellatt, A. (2013) Undergraduate physiotherapy student perceptions of teaching and learning activities associated with clinical education, Physical Therapy Reviews, vol. 18 (6), 439-444.

11. Plush, S. E.,\& Kehrwald, B.A. (2014) Supporting New Academics' Use of Student Centred Strategies in Traditional University Teaching, Journal of University Teaching \& Learning Practice, vol. 11(1), pp. 1-14.

12. Student-Centered Learning. (2014). Education Reform Glossary. http://edglossary .org/ student centered -learning/

13. Tamelis, A. I Studenta Orientuotos Studijos. Available at: http://www4066.vu.lt /Files/File/ Algimantas\%20Tamelis0427_atnaujintas.pdf [Accessed18 November 2014].

14. Tarhan, L., Acar-Sesen, B. (2013) Problem based learning in acids and bases: learning achievements and students' beliefs, Journal of Baltic Science Education, vol. 12 (5), pp.565-577.

15. The World Bank Group (2017). Website: http//www.worldbank.org/depweb/sd.html 